\title{
Lecturers Views of Online Instructors about Distance Education and Adobe Connect
}

\author{
https://doi.org/10.3991/ijet.v15i23.18807 \\ Semih Caliskan ${ }^{(凶)}$ \\ Istanbul Aydin University, Kucukcekmece, Turkey \\ semihcaliskan1@aydin.edu.tr \\ Rashad A. Kurbanov \\ Plekhanov Russian University of Economics, Moscow, Russia \\ Raisa I. Platonova \\ North-Eastern Federal University, Yakutsk, Russia \\ Alfia M. Ishmuradova \\ Kazan Federal University, Nabereznye Chelny, Russia \\ Dinara G. Vasbieva \\ Financial University under the Government of the Russian Federation, \\ Moscow, Russia. \\ Inna V. Merenkova \\ I.M. Sechenov First Moscow State Medical University, Moscow, Russia
}

\begin{abstract}
Due to the epidemic disease COVID-19, all of the trainings and courses have been given via distance education since the spring semester of the 2019-2020 academic year. For the first time, the vast majority of the instructors who delivered these courses offered their courses using Web-based distance education technologies. A new process has been entered due to the epidemic that has affected the world. In this process, educational institutions were caught unprepared. For this reason, since distance education is a new process for most, it is possible for faculty members to face various problems. Therefore, determining the opinions of the instructors about the distance education process is important for the improvement and development of the distance education system. The aim of this study is to examine the opinions of the lecturers who provide online courses via distance education through the distance education system and to make suggestions for the improvement of the system. For this purpose, interviews with semi-structured questions were held with 15 instructors in Adobe Connect application and the obtained data were analysed descriptively. The interviews in the zoom application were recorded. The results of the research determined the opinions of the instructors about technology, online education, competencies, problems and adobe connect. As a result of the research, it revealed that the instructors needed in-service training to have sufficient information about the online training platforms; they had a sufficient
\end{abstract}



communication with the distance education centre in technical problems.

Keywords-Distance education; COVID-19; Adobe Connect; Online Instructors

\section{Introduction}

In December 2019, a local pneumonia outbreak was detected for an initially unknown cause in Wuhan, China, and it was quickly determined that it was caused by a new coronavirus, which is a severe acute respiratory syndrome coronavirus 2 (SARS-CoV-2) [13].

Quarantine is one of the measures taken to prevent the spread of epidemic diseases. This epidemic, which emerged in 2020, has affected the whole world. In order to prevent the spread of the epidemic, precautions like isolation processes have been taken at home. It is estimated that people with quarantine have been exposed to an infectious disease factor, but the level of the disease is unknown, and they are the potential carriers of the disease regardless the symptoms of the disease. The purpose of the quarantine is to disconnect the person likely to be a carrier from other people and reduce the risk of the rest of the community becoming infected [3].

The first quarantine was implemented in Venice for leprosy in 1127, and it emerges as one of the most widely used quarantine examples in history. The biggest quarantines of this century were implemented in 2003 for the SARS virus outbreak, which caused serious acute respiratory syndrome, and the Ebola virus outbreak that affected West Africa and led to quarantine practices in several villages in 2014. These epidemics and these events affect people psychologically [9].

In the spring of 2020, Chinese universities maintained an unprecedented "migration" experience, from face-to-face education to online education in the traditional classroom. Due to the prevalence of Coronavirus disease (COVID-19) in China, most Chinese universities have begun online education in accordance with government requirements for "uninterrupted teaching and learning". Soon, millions of faculties began teaching online at home. Other than China, as of March 13, 61 countries around the world have announced or implemented school and university closures in Africa, Asia, Europe, the Middle East, North America and South America, and most universities have been localized closures. All over the world, education has been transformed into distance education and continued without interruption. This result has led to studies for the search and implementation of the most effective distance education strategies such as effective online teaching.

What is effective online teaching? In the field of teaching efficiency, many studies have been conducted to examine this structure in many different ways. The researchers investigated the validity of student scores, the effects of teacher personality on student scores, the effects of student characteristics on student scores $[5,8]$ the relationship between student grades and student achievement. However, although researchers have made some agreements about the important features of 
effective teaching in traditional classrooms, an effective online teacher may look very different from students. Online learning has become an important way of teaching in higher education. According to the SLOAN-C annual report [2], more than 6.7 million students take at least one online course, and $32 \%$ of current higher education students have taken at least one course online. The transition to online education due to the epidemic is related to the readiness of students. In addition, over $69 \%$ of higher education institutions say that online learning is a critical part of their long-term strategies $[2,4]$.

Numerous research studies, theories, models, standards, and evaluation criteria focus on quality online learning, online teaching, and online course design. What we know from research is that effective online learning results from careful instructional design and planning, using a systematic model for design and development. The design process and the careful consideration of different design decisions have an impact on the quality of the instruction. And it is this careful design process that will be absent in most cases in emergency shifts.

With the technology being developed by each and every educational institution, blended learning is not only more time and cost effective, but also provides a more natural way to learn, work and transform education. Blended education enables organizations that are at the forefront of next-generation learning to be more efficient, faster in implementing change, and more successful in achieving their goals, using different technological structures [21,20].

Social interactions in the classroom mainly include student-teacher interaction and student-student interaction [12,34]. Student-student interaction is also called peer interaction, which refers to the interaction between a student and another individual student or group of students. It is generally accepted that social interactions contribute positively to students' learning. Collaborative learning theory emphasizes that students can expand their knowledge through interactions with other students [29,23]. Many studies in the field of online learning have found that social interaction is important in online interactive environments. For example, Shea, Fredericksen, Pickett, Pelz, and Swan [31] found that the quality and quantity of interactions were important for students' satisfaction in online classes. Paluckaite, and Zardeckaite-Matulaitiene [26], Hrastinski [18] suggests the online learning theory as online participation and is supported by "all kinds of engaging activities that are synonymous and asynchronous with speech or writing, that online learner participation is a complex process and maintains relationships with others, supported by physical and psychological means".

Research in the field of online teaching includes comparisons between traditional courses and online courses, as well as online student and instructor surveys and case studies of individual classes and students. Faherty [37] prepared the school subject and staff's preparation which included physical rearrangement of the class subject, limiting the group work movement of students in the classroom and creating distance learning opportunities for missing days but not for weeks or months during a pandemic. Ash and colleagues assumed that distance learning could be supported by technologies such as the Internet, telephone, radio, TV or telephone messaging or email communication during the Flu Crisis. Interactive video conferencing system design was proposed and implemented in primary schools in Greece. Bai [7] has made 
a project that facilitates collaborative teaching in information systems and has found that the virtual environment should be suitable for other courses as well. Another study on English language teaching and learning was done using the virtual distance learning environment, and it was concluded that virtual environments allowed students to create a world that covered everything they could imagine. Interaction, simulation and collaboration make it possible to learn in an interactive environment [14].

There are many factors that motivate teachers to teach lessons online or increase their satisfaction via online lessons. According to the results of the researches, making flexible programs, applying new teaching methods and techniques, learning new technologies, natural curiosity, sharing information in different ways, and professional development $[19,32,35,26]$ is one of the factors that motivate teachers to teach online. In addition, the online teaching experience affects teachers' motivation and satisfaction with online teaching. Devedzic and Devedzic [12] reported that there was a significant difference between faculty members with distance education experience and faculty members without distance education in their studies in which they examined their perceptions on the value of distance education. According to the results of the study, face to face education has shown to have the most impact on student performance and teacher-student interaction. According to the findings from the findings the factors described as barriers to online learning can be listed as follows: the number of students in the class and the absence of additional payments for the time spent; not being able to get feedback from students visually; concerns about the quality of the content; inadequate education and resources; increased workload; lack of administrative and technical support; lack of online teaching experience; and change in teachers' traditional roles [22].

The diversity of students in online learning environments, the interaction of the students in the classroom and the performance of the students in the course affect the teacher satisfaction in the student dimension. In addition, teachers' belief is that they can increase students' performance and technology use, so professional development and communication with other colleagues are important factors affecting teacher satisfaction. Besides, teachers demand reliable infrastructure and technology. In addition, the value given by the institution where the teachers work for distance education and the support it offers to teachers also affect the satisfaction of teachers at the institutional level [33,35].

It has been online in university due to the epidemic that affects the world. Online training teachers have advantages and disadvantages. Social impact affects students' success. There are studies investigating factors that increase academic success [30] [10]. For this reason, the information of the lecturers who have previously given distance education is very important according to the online course instruction at the university. Some university used Adobe Connect for online lessons. Adobe Connect is synchronous web conferencing software available to colleges and universities. It is important to define instructor perspectives in order to perform the distance education process effectively and efficiently in higher education. Faculty members have to deal with new needs based on new teaching approaches, technology, student guidance, support and flexibility of the process. 


\subsection{Research purpose}

The aim of this study is to examine the opinions of the lecturers who provide online courses via distance education through the distance education system and to make suggestions for the improvement of the system. Due to the spread of this epidemic disease, a state of emergency was declared and all platforms were transferred to online ones. Most education has been given face to face, so students have been used to that. Therefore, online education should be given in the best way as much as the interaction. For this reason, lecturers' opinions about online education are very important. In this research, main focus was given towards determining the opinions of lecturers about online trainings through Adobe Connect program used by many universities in the online education process.

\subsection{Purpose of the study and research questions}

Based on the purpose, the following research questions were posed:

Question 1: What are your opinions about the transition to distance education due to Covid?

Question 2: Were you able to prepare your courses for the online system?

Question 3: What are your suggestions about adobe connect application used in online education?

Question 4: What are your opinions and suggestions about distance education?

\section{Method}

For the purpose of the study to examine the opinions of the lecturers regarding online classes and the suggestions for improving it, an interview and document analysis techniques from qualitative techniques were used. A descriptive approach of study was carried out by interview method, which is one of the qualitative research methods. Hennink, Hutter, and Bailey [17]. Mendelli, [25], stated that the focus of qualitative research is a research model that helps us to understand the participants' own perspectives on a situation or a subject and their comments on the subject and the subject.

\subsection{Data collection tools}

In the research, a semi-structured questionnaire consisting of demographic information form and open-ended questions developed by the researchers was used as a data collection tool. In its final form, 5 open-end questions were addressed to the lecturers. Open-end questions in the questionnaire were created using the literature and the researchers' own experience. A demographic information form was used to determine the instructors' demographics, and a questionnaire was used to determine the faculty's opinion of Adobe Connect. The questionnaire was first reviewed by experienced qualitative research experts, by interviewing 5 faculty members from the 
Department of Computer and Instructional Technologies and necessary corrections were made according to the feedback. In this case, a questionnaire was applied to six trainers outside of the working group for pilot implementation and it was checked whether the questionnaire was understandable.

\subsection{Research group}

A case study approach constituted the methodological basis of this study. This study was conducted in the fall semester 2019-2020 with the participation of 15 lecturers. Semi-structured question-based interviews were conducted with 15 faculty members in Adobe Connect and the results were analysed descriptively. The research working group included educators who were the first to use a distance learning platform and who had never provided online training before. The survey results revealed teachers' positive and negative opinions about the technology, support, management, learning and teaching and content and learning of Adobe connect.

Table 1. Demographic information of the instructors

\begin{tabular}{|l|l|c|}
\hline & & f \\
\hline \multirow{4}{*}{ Gender } & Female & 8 \\
\cline { 2 - 3 } & Male & 7 \\
\cline { 2 - 3 } & Total & 15 \\
\hline \multirow{4}{*}{ gge } & $30-35$ & 3 \\
\cline { 2 - 3 } & $36-40$ & 8 \\
\cline { 2 - 3 } & 41 and more age & 4 \\
\cline { 2 - 3 } & Total & 15 \\
\hline
\end{tabular}

\section{$3 \quad$ Results}

\subsection{Lecturer views on transition to distance education due to Covid}

Table 2. Lecturer views on transition to distance education due to Covid

\begin{tabular}{|l|l|}
\hline \multicolumn{1}{|c|}{ Positive (4) } & \multicolumn{1}{c|}{ Negative (11) } \\
\hline Transition to distance education is positive & Quick transition not provided (8) \\
\hline & Passed unprepared (7) \\
\hline & $\begin{array}{l}\text { Continuous decision changes made in the period } \\
\text { negatively affect the process (5) }\end{array}$ \\
\hline & Equipment shortage not provided (1) \\
\hline
\end{tabular}

When educators' opinions about the transition to distance education due to Covid were examined, they reported negative. They stated that switching the mode of education and carrying it forward was not smooth and easy due to lack of necessary infrastructure and lack of training on technological knowledge. One of the faculty members stated that they had difficulties because the necessary technological equipment was not provided to them. Some of the faculty opinions were as follows: 
"Educational institutions closed suddenly due to Covid. In this process, curfews came. Education was interrupted. The online system was launched for the trainings to continue. The necessary infrastructure was not provided in this process. Equipment was requested, these were not provided by the school. Educational institutions were not ready for this process."

"It is normal for everyone to panic in the cause of the epidemic, which affects the Earth rather than reacting in negative conditions. It is an advantage to switch to online education under these conditions."

\subsection{Adapting the lecture given by lecturer's online}

Table 3. Adapting the lecture given by Lecturer's online

\begin{tabular}{|l|l|}
\hline \multicolumn{1}{|c|}{ Positive (5) } & \multicolumn{1}{|c|}{ Negative (10) } \\
\hline Conformed to the format (5) & Had trouble adapting (8) \\
\hline & Problem changing my presentations (5) \\
\hline & Ask in the question and answer part (2) \\
\hline & couldn't get an application (1) \\
\hline
\end{tabular}

Adapting the lectures were inconvenient for many of the lecturers. About 10 Lecturer's stated that they had difficulty in adapting their lessons to the online system Whereas, 5 lecturers said that they could adapt their lecture notes in accordance with the online system. They stated that they had difficulties in translating the lecture notes from the faculty members who gave negative opinions, and answering students' questions in the same way as in face-to-face education was very much difficult in online system, and could not make students practice in the application sections. However, all of the faculty members who expressed negative opinions stated that these negativities might also be caused by the difficulties themselves not knowing. While taking this finding into consideration into, the faculty members reported another need as an emerged opinion. They stated that they needed to give seminars or trainings about technology supported education in education. Some of the faculty opinions were as follows:

"I adapted my lecture notes very quickly and easily according to online education. I had no problems."

"I can interact while teaching face to face. It is more effective when I look at the eyes of the students and teach lessons. I was talking about the visuals without using a lecture note and I was teaching. But I say it is not suitable for online platform. I had a hard time. Perhaps, if I knew the features of using the system, I would not have experienced this problem." 


\subsection{Lecturer's views on adobe connect technology used in online education}

Table 4. Lecturer's Views on Adobe Connect Technology Used in

Online Education

\begin{tabular}{|l|l|}
\hline \multicolumn{1}{|c|}{ Positive (12) } & \multicolumn{1}{c|}{ Negative (3) } \\
\hline Easy to use (10) & Difficult to use (2) \\
\hline File sharing is easy (8) & Not enough for the lesson (1) \\
\hline Recording (7) & The camera image is small (1) \\
\hline synchronous asynchronous feature (6) & Audio and video are difficult to allow (1) \\
\hline
\end{tabular}

This part of the study dealt with the acceptance of Adobe connect technology as an alternative form of education by Lecturers. About 12 of the faculty members gave positive opinions about Adobe Connect, 3 Lecturers gave negative opinions. There are 10 faculty members who stated that the program was easy to use. Six faculty members stated that they could simultaneously conduct lectures, record the lectures, and then watch the lectures of the lecturer whenever they wanted. In addition, there are faculty members who expressed their negative opinions. 2 faculty members stated that adobe connect program was difficult to use. One faculty member stated that it was difficult to share audio and images. Some of the faculty opinions were as follows:

"The Adobe Connect program is very easy to use. This is a great feature to listen to the voice of the students that I want or open their images. I am interactive with my students while taking classes."

"I receive confirmation from the students before clicking the save button in my lessons. Is there a problem with my voice or video? After receiving the confirmation, I press the record button and my course is recorded. At the end of the lesson, I click on the end meeting option. Students and I can watch my lesson any time we want. This program is easy and its features are very nice.

\subsection{Views and suggestions of faculty members towards distance education}

Table 5. Views and suggestions of faculty members towards distance education

\begin{tabular}{|l|c|}
\hline & f \\
\hline Teacher training about online courses & 10 \\
\hline Student training about online courses & 8 \\
\hline Necessary controls by experts during the lesson & 5 \\
\hline Adequate support by the distance learning centre & 4 \\
\hline
\end{tabular}

Finally, suggestions and views of the faculty members were taken. Where about 10 lecturers expressed that the teachers foremostly needed a training for online courses. Following what 8 lecturers suggested that students training was as important as teachers training was. While another 5 of them said that there should be a specialist check of the system during the live sessions and lastly 4 educators suggested providing adequate support more frequently by the distance learning centre. 


\section{Discussion and Conclusion}

Teachers view on the transition to distance learning have concluded that the successful process of online training cannot be expedited. Due to the fact that educational institutions are unprepared for extraordinary situations. Lack of necessary infrastructure related to online education was interrupted for a while, so the system was made ready and education continued. In this process, it was concluded that they experienced problems due to not receiving technological support. In this finding, technology-supported trainings of lecturers may be increased, and more support may be required regarding the use of technology. One of the lecturers stated that they had difficulties because they did not provide technological equipment. It can be concluded that lecturers should be provided with computers and equipment of the institution they work in. In his study, Gürer, Tekinarslan, and Yavuzalp [16] addressed the problems they faced in teaching instructors about distance education. Providing not only technical support but also pedagogical and material support will contribute to facilitating the adaptation of lecturers to online classes and increasing their performance [22].

It was concluded that among the lecturers, 5 lecturers adapted the lecture notes according to the online system. From the technical point of view, concluding that the lecturers using computer literacy, different methods and techniques adapted their content easily. It was concluded from the faculty members who gave negative opinions that they had difficulty translating the lecture notes. It was concluded that the instructors, who stated that they used Powerpoint, animation, question and answer techniques, received support when adapting them to online education. However, all the faculty members who gave negative feedback said that these negative comments were also due to difficulties which they did not know about themselves. From these findings, it was concluded that technical information should be given about how the academic staff should activate the students in online education, how they see the students, and how to add them to the course. Lloyd, Byrne, \& McCoy, [22] in study, examined faculty-based barriers in online education. In their study, it was concluded that there were technical problems, technical equipment, and guidance deficiencies. As a result of the literature review, the deficiencies of the teachers about online lessons were revealed. In-service trainings and their competencies can be increased in technology supported trainings [28,12,6,33,27].

Of the lecturers teaching using Adobe Connect program, 12 faculty members gave positive opinions about Adobe Connect, while 3 instructors gave negative opinions. There are 10 faculty members who stated that the program was easy to use. Faculty members stated that they could record the lesson and then watch the lessons of the lesson at any time. There are also faculty members who gave negative opinions. 2 faculty members stated that the use of adobe connect examination is difficult. One faculty member stated that it was difficult to share audio and video. Looking at the result of all this finding, it has turned out that Adobe Connect application is an easy lecture program. Adobe connect application, one of the online education platforms, is a platform that interacts students and teachers interactively. The platform with many features provides a sufficient level of support service $[15,23]$. 
In the conclusions on suggestions and opinions on distance education, it was concluded that 10 teachers had technical requirements. Furthermore, it was concluded that there should be teacher training in addition to student training. Online training and advice on the system can be provided to teachers and students. Via online education, trainings can be given on how to interact with technologies. They stated that one member of the technical team should be present in class during the synchronous education. Hence, it concluded that any problem might continue without delay by getting help from the technical team immediately. The number of staffs can be increased so that the support given by the distance education centre staff to the lecturers is faster.

\section{$5 \quad$ References}

[1] Alipour, M., \& Tajfar, S. (2019). Investigating ( $\mathrm{Im}$ )politeness in online forums between English speakers and English as a foreign language learners. Global Journal of Foreign Language Teaching, 9(3): 137-156. https://doi.org/10.18844/gjflt.v9i3.4205

[2] Allen, I. E., \& Seaman, J. (2013). Changing Course: Ten Years of Tracking Online Education in the United States. Sloan Consortium. PO Box 1238, Newburyport, MA 01950 .

[3] American Psychiatric Association. (2013). Diagnostic and Statistical Manual of Mental Disorders (5th edition). Washington, DC: Author.

[4] Antropova, M., Vlasov, A., \& Kasyanenko, E. (2019). Mobile technologies in educational process Chinese universities. New Trends and Issues Proceedings on Humanities and Social Sciences, 6(5): 1-7. https://doi.org/10.18844/prosoc.v6i5.4367

[5] Arbuckle, J., and Williams, B. D. (2003). Students' perceptions of expres- siveness: Age and gender effects on teacher evaluations. Sex Roles: A Journal of Research 49 (9-10): 507-516. https://doi.org/10.1023/A:1025832707002

[6] Ateş, A., \& Altun, E. (2008). Bilgisayar Öğretmeni Adaylarının Uzaktan Eğitime Yönelik Tutumlarının Çeşitli Değişkenler Açısından İncelenmesi. Gazi University Journal of Gazi Educational Faculty (GUJGEF), 28(3). https://doi.org/10.17556/erziefd.305902

[7] Bai, Y., Yao, L., Wei, T., Tian, F., Jin, D. Y., Chen, L., \& Wang, M. (2020). Presumed asymptomatic carrier transmission of COVID-19. Jama, 323(14): 1406-1407. https://doi. org/10.1001/jama.2020.2565

[8] Centra, J. A., and N. B. Gaubatz. (2000). Is there gender bias in student eval- uations of teaching? The Journal of Higher Education 70 (1): 17-30. https://www.jstor.org/stable/ 2649280

[9] Çakmak, S., \& Nural, N. (2019). Is the Spirituality Effective on Psychosocial Adjustment in Patients with Chronic Disease? International Journal of Emerging Trends in Health Sciences, 3(1): 29-33. https://doi.org/10.18844/ijeths.v3i1.4209

[10] Deldoost, M., Mohammadzadeh, P., Akbari, A., \& Saeedi, M. T. (2019). On the relationship between cognitive ability and field of study. Global Journal of Psychology Research: New Trends and Issues, 9(1): 1-7. https://doi.org/10.18844/gjpr.v9i1.3928

[11] Demir, S., \& Bozkurt, A. (2011). İlköğretim matematik öğretmenlerinin teknoloji entegrasyonundaki öğretmen yeterliklerine ilişkin görüşleri. İlköğretim Online, 10(3), 850860. https://doi.org/10.21547/jss.256844 
[12] Devedzic, V., \& Devedzic, M. (2019). Technology-Enhanced Assessment at universities and in schools: An initiative. International Journal of Learning and Teaching, 11(3), 89-98. https://doi.org/10.18844/ijlt.v11i3.4319

[13] Dong, E., Du, H., \& Gardner, L. (2020). An interactive web-based dashboard to track COVID-19 in real time. The Lancet infectious diseases, 20(5): 533-534. https://doi.org/10. 1016/S1473-3099(20)30120-1

[14] Mujber, T. S., Szecsi, T., \& Hashmi, M. S. (2004). Virtual reality applications in manufacturing process simulation. Journal of materials processing technology, 155, 18341838. https://doi.org/10.1016/i.jmatprotec.2004.04.401

[15] Englehart, D. S. (2016). Explorations in online learning using Adobe Connect. International Journal of Learning, Teaching and Educational Research, 14(2).

[16] Gürer, M. D., Tekinarslan, E., \& Yavuzalp, N. (2016). Çevrimiçi Ders Veren Öğretim Elemanlarının Uzaktan Eğitim Hakkındaki Görüşleri. Turkish Online Journal of Qualitative Inquiry, 7(1). https://doi.org/10.17569/tojqi.74876

[17] Hennink, M., Hutter, I., \& Bailey, A. (2020). Qualitative research methods. SAGE Publications Limited.

[18] Hrastinski, S. (2009). A Theory of Online Learning as Online Participation. Computers \& Education, 52(1): 78-82. https://doi.org/10.1016/j.compedu.2008.06.009

[19] Helsel, S. (1992). Virtual reality and education. Educational Technology, 32(5): 38-42.

[20] Martín-Gutiérrez, J., Mora, C. E., Añorbe-Díaz, B., \& González-Marrero, A. (2017). Virtual technologies trends in education. EURASIA Journal of Mathematics, Science and Technology Education, 13(2), 469-486. https://doi.org/10.12973/eurasia.2017.00626a

[21] Konst, T., \& Kairisto-Mertanen, L. (2019). Developing innovation pedagogy. Contemporary Educational Researches Journal, 9(3), 74-84. https://doi.org/10.18844/cerj. v9i3.4224

[22] Lloyd, S. A., Byrne, M. M., \& McCoy, T. S. (2012). Faculty-perceived barriers of online education. Journal of online learning and teaching, 8(1).

[23] Longhi, E., \& Angelini, C. (2015). How to Use Adobe Connect for Oral Language Practice in International Virtual Classes. In ICT for Language Learning International Conference, Florence, Italy, 12-13 November 2015 (pp. 143-47).

[24] Macfadyen, L. P., \& Dawson, S. (2010). Mining LMS Data to Develop An "Early Warning System" For Educators: A Proof Of Concept. Computers \& Education, 54(2): 588- 599. https://doi.org/10.1016/j.compedu.2009.09.008

[25] Mendelli, S. (2019). Determination of mathematics teachers' opinions related to response and solution-based software in secondary education institutions. Global Journal of Information Technology: Emerging Technologies, 9(2), 41-50. https://doi.org/10.18844/g jit.v9i2.4421

[26] Paluckaite, U., \& Zardeckaite-Matulaitiene, K. (2019). A systematic literature review on psychosocial factors of adolescents' online self-disclosure. New Trends and Issues Proceedings on Humanities and Social Sciences, 6(1): 47-64. https://doi.org/10.18844/pros oc.v6i1.4154

[27] Parmaksız, R., \& Sicak, A. (2015). Uzaktan hizmetiçi eğitime ilişkin öğretmen görüşleri. Uşak Üniversitesi Sosyal Bilimler Dergisi, 8(4): 187-212. https://doi.org/10.12780/uusbd. $\underline{96271}$

[28] Porcello, D., \& Hsi, S. (2013). Crowdsourcing and curating online education resources. Science, 341(6143): 240-241.

[29] Roberts, T. S. (2004). Online Collaborative Learning: Theory and Practice. Information Science Publishing. 
[30] Savarese, G., Pecoraro, N., Fasano, O., Mollo, M., Iannaccone, A., Manzi, F., \& Curcio, L. (2019). Perceived Social Support and Clinical Symptomatology in Italian University Students. Global Journal of Guidance and Counseling in Schools: Current Perspectives, 9(3): 90-94. https://doi.org/10.18844/gigc.v9i3.4121

[31] Shea, P., Fredericksen, E., Pickett, A., Pelz, W., \& Swan, K. (2001). Measures of Learning Effectiveness in The SUNY Learning Network. In Online Education: Proceedings of the 2000 Sloan Summer Workshop on Asynchronous Learning Networks, 31-54. https://doi. org/10.24059/olj.v4i3.1897

[32] Swan, K., Shea, P., Richardson, J., Ice, P., Garrison, D. R., Cleveland-Innes, M., \& Arbaugh, J. B. (2008). Validating A Measurement Tool of Presence in Online Communities of Inquiry. E-Mentor, 2(24): 1-12.

[33] Taşlıbeyaz, E., Karaman, S., \& Göktaş, Y. (2014). Öğretmenlerin Uzaktan Hizmet İçi Eğitim Deneyimlerinin İncelenmesi. Ege Eğitim Dergisi, 15(1): 139-160. https://doi.org/ 10.12984/eed.19099

[34] Thinnukool, O., Khuwuthyakorn, P., \& Wientong, P. (2017). Pharmacy assistant Mobile application (PAMA): development and reviews. International Journal of Interactive Mobile Technologies (iJIM), 11(3): 178-194. https://doi.org/10.3991/ijim.v11i3.6757

[35] Hariadi, B., Sunarto, M. J. D., Sudarmaningtyas, P., \& Jatmiko, B. (2019). Hybrid learning by using brilian applications as one of the learning alternatives to improve learning outcomes in college. International Journal of Emerging Technology in Learning, 14(10): 34-45. https://doi.org/10.3991/ijet.v14i10.10150

[36] Karabatzaki, Z., Stathopoulou, A., Kokkalia, G., Dimitriou, E., Loukeri, P., Economou, A. \& Drigas, A. (2018). Mobile application tools for students in secondary education: An evaluation study. International Journal of Interactive Mobile Technologies, 12(2), 142-161. https://doi.org/10.3991/ijim.v12i2.8158

[37] Uscher-Pines, L., Schwartz, H. L., Ahmed, F., Zheteyeva, Y., Leschitz, J. T., Pillemer, FUzicanin, A. (2020). Feasibility of Social Distancing Practices in US Schools to Reduce Influenza Transmission During a Pandemic. Journal of Public Health Management and Practice. https://doi.org/10.1097/phh.0000000000001174

\section{Authors}

Semih Caliskan was born in 1992 in Akhisar, graduated from the computer and instructional technology teacher at the age of 22, then started a master's degree and completed the same department in 2 years and started a doctorate. Semih Caliskan is lecturer. of İstanbul Aydın University, Department of Distance Learning Centre of İstanbul Aydin University. His research technology, computer and special learning. He has more than 10 published papers in web of science and Scopus. E-mail id: semihcaliskan1@aydin.edu.tr

Rashad A. Kurbanov is a Doctor in Law, Professor, Head of the Department of Civil Law Disciplines at Plekhanov Russian University of Economics, Moscow, Russia (36 Stremyannyi Pereulok, 115093, Moscow, Russia). He is well known in Russia with his scientific works dedicated to the different problems of government, legislation and comparative law. He is also interested on the problems concerning the methodology of scientific works. E-mail: mos-ssp@mail.ru

Raisa I. Platonova is a Doctor of Education, Professor of the Faculty of Road Construction at the North-Eastern Federal University named after M.K. Ammosov (58 
Belinsky Street, 677000, Yakutsk, Russia). She is interested in the following problems: adult education, emerging technologies, teacher education, science education. She is well known as a scientist not only in Russia, but also abroad. Email: platonova_raisa@mail.ru

Alfia M. Ishmuradova is $\mathrm{PhD}$ in Pedagogy, Associate Professor of the Department of Foreign Languages at Kazan Federal University in Nabereznye Chelny Institute (branch) of Kazan (Volga) Federal University (18 Kremlyovskaya Street, 420000 , Kazan, Russia). She has a large number of articles included in international citation databases, is a productive author. Her research interests for the last decade have been connected with project work and as well as problems of teaching English to students of non-linguistic universities. She has more 30 articles published in international journals and conferences materials. E-mail: alfiaishmuradova@mail.ru

Dinara G. Vasbieva is PhD in Economics, Associate Professor of the Department of Foreign Languages at Financial University under the Government of the Russian Federation (49 Leningradsky prospect, 125993, Moscow, Russia). Her research interests for the last decade have been largely concerned with the problems of methodology in education and linguistics, e-learning environment and energy saving economics. She has more than 70 articles published in different international journals. E-mail: dinara-va@ list.ru

Inna V. Merenkova is an assistant of Human Anatomy Department at the First Moscow State Medical University (Sechenov University) (2 bld.4 Bolshaya Pirogovskaya Street, 119435, Moscow, Russia). Her main scientific and professional interests are associated with teaching (training and methodological) activities, scientific research and educational activities. The main task is to develop the content and methods of teaching the subject of anatomy, the development of new principles, methods, systems and technologies for teaching the subject. E-mail: biene22@mail.ru

Article submitted 2020-09-26. Resubmitted 2020-10-27. Final acceptance 2020-10-27. Final version published as submitted by the authors. 